\title{
Physical Activity Modulating Lipid Metabolism in Gallbladder Diseases
}

\author{
Harshitha Shanmugam $^{1^{*}}$, Emilio Molina-Molina ${ }^{1^{\star}}$, Domenica Maria Di Palo ${ }^{1}$, Maria Felicia Faienza ${ }^{2}$, Agostino Di \\ Ciaula $^{1}$, Gabriella Garruti ${ }^{3}$, David Q.-H. Wang ${ }^{4}$, Piero Portincasa ${ }^{1}$
}

1) Clinica Medica "A. Murri",

Department of Biomedical

Sciences \& Human Oncology, University of Bari Medical

School, Bari, Italy

2) Department of Biomedical

Sciences and Human

Oncology, Paediatric Section,

University of Bari "A. Moro",

Bari, Italy

3) Section of Endocrinology,

Andrology and Metabolic

Diseases, Department of

Emergency and Organ

Transplants, University of Bari Medical School, Bari, Italy

4) Department of Medicine,

Division of Gastroenterology

and Liver Diseases, Marion

Bessin Liver Research Center, Albert Einstein College of

Medicine, Bronx, NY 10461, USA

\section{Address for correspondence: Piero Portincasa Clinica Medica "A. Murri" Dept. of Biomedical Sciences \& Human Oncology University "Aldo Moro" Medical School Policlinico Hospital, Piazza G. Cesare 11 - 70124 Bari, Italy piero.portincasa@uniba.it}

Received: 27.10.2019 Accepted: 28.01.2020

\footnotetext{
* These authors have contributed equally
}

\section{ABSTRACT}

Physical activity encompasses a series of overall benefits on cardiovascular health and metabolic disorders. Research has recently focused on the hepatobiliary tract, as an additional target of the health-related outcomes of different types of physical exercise. Here, we focus on the global features of physical activity with respect to exercise modality and intensity, and on studies linking physical activity to lipid metabolism, gallbladder diseases (gallstones, symptoms, complications and health-related quality of life), gallbladder motor-function, enterohepatic circulation of bile acids, and systemic metabolic inflammation. Additional studies need to unravel the pathophysiological mechanisms involved in both beneficial and harmful effects of physical activity in populations with different metabolic conditions.

Key words: bile acids - gallbladder disease - lipids - physical activity.

Abbreviations: BA: bile acid; BMI: body mass index; CVD: cardiovascular disease; HDL: high-density lipoprotein; HRQoL: health-related quality of life; LDL: low-density lipoprotein; MET: metabolic equivalent task; T2D: type 2 diabetes.

\section{INTRODUCTION}

The majority of the elderly population suffers from several chronic diseases [1]. Sedentary lifestyles certainly play a major role in this respect [2], and contribute to negative effects on quality of life [3], the cardiovascular system, and overall health status [4]. Lack of physical exercise contributes to the rise of non-communicable diseases such as obesity, type 2 diabetes (T2D), cardiovascular disease (CVD), and premature mortality in the long-term [5]. This unfavorable condition already starts during childhood and adolescence [6]. By contrast, regular physical activity, along with healthy lifestyles, reduces the risk of CVD [5], providing beneficial effects on various chronic diseases [2], including obesity and $\mathrm{T} 2 \mathrm{D}$, the main components of the metabolic syndrome. The benefits of physical activity might extend to dyslipidemia and to the hepatobiliary tract, i.e., gallbladder and cholesterol cholelithiasis [7-9], one of the "fellow travelers" with the metabolic syndrome $[8,10]$.

In this paper, we focus on the mechanisms linking physical activity to lipid metabolism and pathophysiological mechanisms of gallbladder diseases.

\section{GLOBAL FEATURES OF PHYSICAL ACTIVITY}

Physical activity is a sustained body movement, generating an increased energy expenditure [11]. Planned, regularly, repeated and intentional physical exercise maintains health and fitness (Table I) $[11,12]$. Aerobic capacity is a regular activity allowing vigorous tasks without undue fatigue and can be related to general health (muscular endurance, mobility, muscular strength, body composition) or to skill improvement (balance, agility, power, coordination, reaction time) [11].

Determination of exercise intensity relies on the calculation of specific parameters. Monitoring of physical activity is based on metabolic equivalent tasks (METs), which is representative of the volume of oxygen $\left(\mathrm{VO}_{2}\right)$ consumed during a certain physical activity (one MET $=3.5 \mathrm{~mL} / \mathrm{kg} / \mathrm{min}$ ) $[11,13]$. A MET is the ratio of the rate of energy expended during an activity to the rate of energy expended at rest, i.e., $1 \mathrm{MET}$ is the rate of 
Table I. Different effects of physical activity by exercise modality.

\begin{tabular}{|c|c|c|}
\hline Exercise modality & Examples & Effects \\
\hline Aerobic exercise & $\begin{array}{l}\text { - Walking } \\
\text { - Running }\end{array}$ & $\begin{array}{l}\text { Favours endurance and } \\
\text { increases cardiovascular and } \\
\text { respiratory fitness }\end{array}$ \\
\hline Strength exercise & $\begin{array}{l}\text { - Weight lifting } \\
\text { - Bodyweight } \\
\text { resistance }\end{array}$ & $\begin{array}{l}\text { Helps increase muscular } \\
\text { resistance and strength }\end{array}$ \\
\hline Balance exercise & $\begin{array}{l}\text { - Tai chi } \\
\text { - Heel-toe walking }\end{array}$ & $\begin{array}{l}\text { Improves balance, } \\
\text { proprioception and prevents } \\
\text { falls }\end{array}$ \\
\hline Mobility exercise & $\begin{array}{l}\text { - Yoga } \\
\text { - Stretching }\end{array}$ & $\begin{array}{l}\text { Maintains and improves joint } \\
\text { motions and increases muscle } \\
\text { lengthening }\end{array}$ \\
\hline
\end{tabular}

energy expenditure while at rest. A 5 METs activity therefore is equal to 5 times the energy used at rest. Thus, performing a 5 METs activity for 60 minutes, means 5 x $60=300$ METminutes or $5 \mathrm{METs} /$ hour of physical activity. Scientifically, 500 to 1000 MET-minutes total weekly physical activity produces substantial health benefits for adults, and there is a dose-response beneficial effect already starting below 500 .The intensity of aerobic physical activity can be better classified into three absolute groups, also according to US Department of Health and Human Services, 2008 Physical Activity Guidelines for Americans (https://health.gov/paguidelines/2008/pdf/ paguide.pdf) $[14,15]$ :

- Light-intensity activities are defined as 1.1 to 2.9 METs;

- Moderate-intensity activities are defined as 3.0 to 5.9 METs;

- Vigorous-intensity activities are defined as 6.0 METs or more.

In this respect, walking at $5.3 \mathrm{~km}$ per hour requires 3.3 METs of energy expenditure (i.e. moderate-intensity activity), while running at $9.6 \mathrm{~km}$ per hour is a 10 METs activity (i.e., vigorous-intensity activity).

In contrast to unmodifiable risk factors such as genetics, age, and gender, physical inactivity is a modifiable risk factor. Clinicians should prescribe daily physical activity of at least 30 min duration to all subjects, as part of a well-structured lifestyle program. Even moderate-intensity exercise brings beneficial health effects [11]. Recent physical activity guidelines for adults from USA, Canada, Australia and Europe recommend at least $150 \mathrm{~min} /$ week of moderate-intensity exercise, such as brisk walking, or at least $75 \mathrm{~min} /$ week of vigorous-intensity exercise, such as heavy weightlifting [16-20]. It is a fact that unfit individuals have increased risks of mortality (2-3 times more) when compared to fitter individuals. This alarming trend occurs regardless of body composition or presence of CVD [21].

\section{GENERAL EFFECTS OF PHYSICAL ACTIVITY ON LIPID METABOLISM}

A large meta-analysis showed that physical activity holds several beneficial effects on lipid metabolism: decreased serum triglycerides and cholesterol [22], and increased in serum high-density lipoprotein (HDL) levels [22-24]. This association is linked particularly to increased aerobic capacity ( $\mathrm{VO}_{2}$ peak) [25]. Of note, serum HDL represents a marker of reverse cholesterol transport to liver [26,27], a step acting as the precursor of bile acid synthesis [28]. In turn, this HDLmediated pathway could participate in mechanisms leading to decreased biliary cholesterol saturation [27]. In line with this possibility, serum HDL levels are inversely related to gallstone prevalence (see below) [29]. The favorable effects of physical exercise might also extend to the control of the fatty acid-dependent hypersecretion of gallbladder mucin [30,31], another major factor involved in the pathogenesis of cholesterol cholelithiasis [32-34].

Adolescents performing a higher amount of physical activity have lower body fat composition and more favorable HDL cholesterol [35]. Noteworthy, in the cited study, almost $48 \%$ of participants did not meet the daily physical activity recommendations. Also, in pre-adolescent girls, intensity of physical activity is a more important determinant of lowdensity lipoprotein (LDL)cholesterol than energy spent in exercising [36]. Indeed, in another study in men, physical activity over $9 \mathrm{kcal} /$ minute (i.e., vigorous) was associated with a decreased serum total cholesterol and triglycerides, as well as increased aerobic fitness [37]. Slightly decreased triglycerides and increased HDL cholesterol levels were also observed in Brazilian participants performing vigorous physical activity [38]. Thus, long-term physical activity should be promoted in order to improve the lipid profile of gallstone patients, with special emphasis to the number of steps and intensity of performance, which accelerates fat oxidation in the body [13].

\section{GALLSTONE DISEASE}

The prevalence and incidence of cholelithiasis (i.e. the physical presence of solid concrements, stones, in the gallbladder) are rising worldwide. About $20 \%$ of adults in developed countries have gallstones [32], with an incidence rate of new cases of $0.6-1.39 \%$ per year [39]. About 20 million Americans and $10-15 \%$ of adults in Europe suffer from gallbladder disease $[32,40]$. Aging is associated with an increasing prevalence of gallstones which remains markedly higher in women than in men [41]. Although gallstones remain asymptomatic, about $20 \%$ of gallstone patients will develop symptoms (colicky pain) and/or complications during their lifetime (acute/ chronic cholecystitis, cholesterolosis and gallbladder polyps, gallbladder cancer, acute pancreatitis, biliary obstruction, acute cholangitis, biliary enteric fistula and gallstone ileus, choledocholithiasis, or recurrent pyogenic cholangitis) $[42,43]$. Such complications are frequently characterized by critical care aspects $[10,44]$. Thus, cholelithiasis is still the most common gastroenterological cause of hospital admissions across Europe [45], and the socioeconomic costs of cholelithiasis remain very high. Approximately $75 \%$ of gallstones in westernized countries consist mainly of packed cholesterol monohydrate crystals [32, 41, 46-48]. The remaining 25\% of gallstones are either black pigment stones in $20 \%$ (polymerized calcium bilirubinate) growing in the gallbladder or brown pigment stones in 5\% (mostly calcium bilirubinate), growing in the infected extrahepatic or intrahepatic bile ducts [33, 41, 47, 49, 50]. The increasing trends of cholelithiasis parallel the rise in obesity [51, 52], T2D [53-56], insulin resistance [56, 57] and metabolic syndrome [48] worldwide. Additional risk factors 
are reduced serum HDL, hypertriglyceridemia [58], sedentary lifestyles [59, 60], hormone replacement therapy [59], and fast-food consumption [59]. Along with obesity, the risk of developing symptomatic gallstones prone to cholecystectomy, is increasing [61-67].

The most important pathogenic factors for cholesterol gallstones are depicted in Fig. 1 and include: a) predisposing genetic factors and lithogenic (LITH) genes $[68,69]$; b) hepatic factors leading to the hypersecretion of cholesterol, which in turn promote a sustained supersaturated gallbladder bile [70]; c) rapid phase transition of increased biliary cholesterol, contributing to the precipitation and aggregation of solid cholesterol crystals [71, 72]; d) defective gallbladder motility and immune-mediated inflammation, with hypersecretion of mucin gel by the epithelium and luminal accumulation [73]; e) intestinal factors involving slow transit, increased cholesterol absorption from the small intestine, decreased bile absorption and modified gut microbiota [27, 42, 43] (Fig. 1).

\section{GENERAL EFFECTS OF PHYSICAL ACTIVITY ON THE GALLBLADDER, HEPATOBILIARY TRACT, AND SYSTEMIC PATHWAYS}

Physical activity influences gallbladder function and contributes to the reduction of the risk of gallstones and gallstone disease (i.e., symptoms, complications due to the presence of gallstones). The main effects of physical activity on gallbladder and hepatobiliary tract according to population studies appear in Table II. Evidence shows that several mechanisms, also independent on the gallbladder per se, can be involved.

Mechanisms linking the potential beneficial effects of aerobic exercise to gallstone disease include hepatic cholesterol synthesis, absorption and secretion, gallbladder and intestinal motility, and neuro-hormonal pathways [51, 60, 74-77]. In the study of Utter et al. [78], in obese women, significant gallbladder emptying occurred for both exercise (five $45 \mathrm{~min}$ brisk walking sessions per week at $75.2 \pm 0.5 \%$ of maximum heart rate) and control, either pre- or post intervention. The exercise group had increased gallbladder ejection fraction after exercise training $(39.5 \pm 4.9 \%$ to $54.7 \pm 6.5 \%)$ but this $15.2 \%$ increase did not differ from that seen in the controls [78]. American Indians have a high risk of cholesterol gallstones and metabolic disorders. In 3,143 subjects of both sexes, from 13 American Indian communities examined at baseline in 198992 and at an ultrasonographic follow-up in 1993 and 1995, the authors found that physical activity was inversely related to the development of gallbladder disease. Outcomes of this study were independent from potential confounders as body mass index (BMI) and sex, but could have been influenced by the presence of diabetes [79].

Questionnaire-based surveys reported that physical activity could reduce the risk of symptomatic gallstones by onethird $[60,74,79-81]$. Conversely, overnutrition and physical inactivity are the main factors which lead to a high risk of

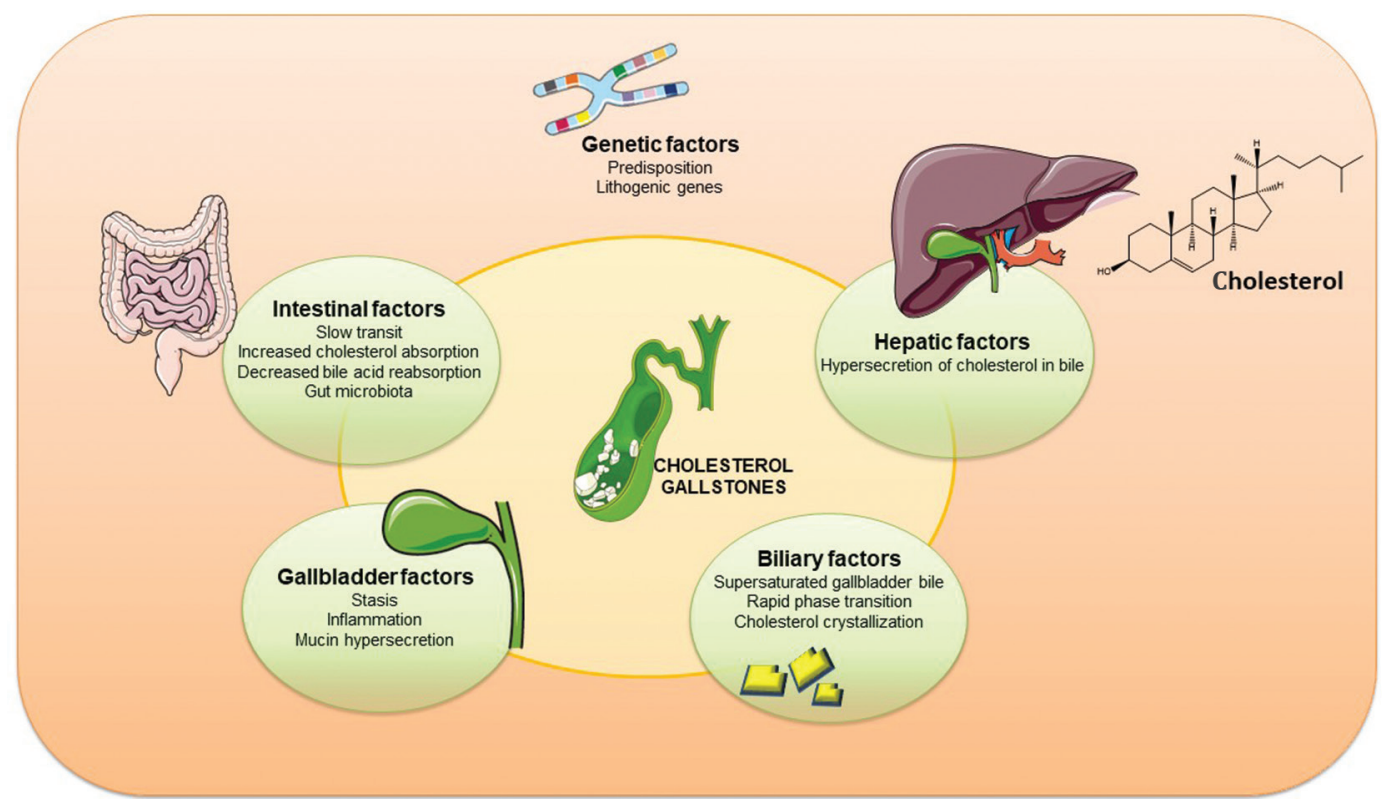

Fig. 1. Pathogenetic factors involved in the formation of cholesterol gallstones. Current research is focusing on several overlapping pathways, and the preeminent role of cholesterol across such pathways is depicted by the chemical formula: - genetic factors (i.e., polygenic predisposition or role of specific lithogenic genes); - hepatic factors (i.e., mainly hypersecretion of biliary cholesterol); - biliary factors (i.e., supersaturated gallbladder bile due to re-absorption of water from the gallbladder epithelium, propensity to transition of liquid micellar cholesterol to concentrated vesicular cholesterol, precipitation of excess cholesterol into solid anhydrous/monohydrate crystals which aggregate and form the first nucleus of cholesterol gallstones); - gallbladder factors (i.e., hypomotile viscus predisposing to stasis of supersaturated, mucin-enriched bile in a chronically inflamed gallbladder); intestinal factors (i.e., sluggish intestine predisposing to increased absorption of dietary and re-circulating biliary cholesterol, decreased bile acid reabsorption and effect of intestinal, mainly colonic microbiota, on biotransformation of primary bile acids into secondary -more lithogenic- bile acids). Adapted from [10, 27, 40, 43, 44, 70, 122, 150-157]. 
Table II. Main beneficial effects of physical activity on gallbladder by population studies

\begin{tabular}{|c|c|c|c|c|}
\hline Study groups & Country & $\begin{array}{l}\text { Physical activity } \\
\text { recording }\end{array}$ & Outcomes & Reference \\
\hline $\begin{array}{l}\text { European Prospective Investigation } \\
\text { of Cancer (EPIC-Norfolk) Study. } \\
25,639 \text { volunteers, aged } 40-74 \text { years } \\
\text { monitored over } 14 \text { years }\end{array}$ & UK & $\begin{array}{l}\text { Questionnaire } \\
\text { (classification of physical } \\
\text { activity into four types) }\end{array}$ & $\begin{array}{l}\text { After } 5 \text { years of follow-up, } 135 \text { participants } \\
(69.6 \% \text { women) developed symptomatic } \\
\text { gallstones. } 70 \% \text { decreased risk of gallstones with } \\
\text { the highest level of physical activity, compared } \\
\text { with the lowest three levels. }\end{array}$ & {$[85]$} \\
\hline $\begin{array}{l}\text { Population-based cohort of } 3,143 \\
\text { men and women, } 45-74 \text { yr of } \\
\text { age, from } 13 \text { American Indian } \\
\text { communities monitored at baseline } \\
\text { (1989-1992) and at follow-up (1993- } \\
1995)\end{array}$ & USA & $\begin{array}{l}\text { Questionnaire (METs/ } \\
\text { week) }\end{array}$ & $\begin{array}{l}\text { Out of the 2,130 gallstone-free subjects, } \\
650 \text { individuals ( } 403 \text { women and } 247 \text { men) } \\
\text { developed gallbladder disease according to } \\
\text { ultrasound or had cholecystectomy. Increased } \\
\text { activity levels were inversely related to } \\
\text { gallbladder disease status, and in patients } \\
\text { without diabetes. }\end{array}$ & [79] \\
\hline $\begin{array}{l}\text { Study of Osteoporotic Fractures } \\
\text { (SOF; 1986-1988), } 8,010 \text { post- } \\
\text { menopausal women }\end{array}$ & USA & $\begin{array}{l}\text { Harvard Alumni } \\
\text { Questionnaire (kcal/ } \\
\text { week) }\end{array}$ & $\begin{array}{l}\text { Women in the lowest two quartiles of physical } \\
\text { activity had a } 59 \% \text { and a } 57 \% \text { higher risk of } \\
\text { developing gallstone disease compared to } \\
\text { women in the highest quartile of physical } \\
\text { activity. Physical activity inversely related to } \\
\text { the development of gallstone disease in post- } \\
\text { menopausal women independent of body mass } \\
\text { index. }\end{array}$ & {$[80]$} \\
\hline $\begin{array}{l}\text { Ultrasonographic study: } \\
100 \text { subjects with gallstones vs. } 290 \\
\text { randomly selected control subjects }\end{array}$ & Italy & Questionnaire (MJ/week) & $\begin{array}{l}\text { Physical activity inversely associated with risk of } \\
\text { gallstone formation. }\end{array}$ & {$[75]$} \\
\hline $\begin{array}{l}\text { Prospective cohort study: } \\
45,813 \text { men } 40 \text { to } 75 \text { years of age were } \\
\text { followed from } 1986 \text { to } 1994 \text {. }\end{array}$ & USA & $\begin{array}{l}\text { Questionnaire (METs/ } \\
\text { week) }\end{array}$ & $\begin{array}{l}828 \text { men with symptomatic gallstones } \\
\text { (ultrasonography, radiology, cholecystectomy). } \\
\text { Increased physical activity was inversely related } \\
\text { to risk for symptomatic gallstone disease. }\end{array}$ & {$[74]$} \\
\hline
\end{tabular}

Abbreviations: kcal: kilocalories; METs: metabolic equivalent tasks; MJ: megajoules.

CVD, and are major precursors of increased BMI and hepatic cholesterol synthesis rate [33]. Metabolically-active visceral fat deposition, moreover, increases gastrointestinal morbidity and mortality due to gallstone disease, tumors, and endoscopy complications [82]. Low levels of physical activity and serum cholesterol levels represent risk factors for gallbladder disease. The increase in serum HDL levels are inversely associated with gallstone prevalence [29], and regular exercise promotes this increase $[23,24]$. Notably, physical activity decreases the risk of cholesterol gallstone formation independently of weight loss, also by improving several metabolic abnormalities such as hyperinsulinemia, high plasma triglycerides and low serum HDL [74].

In a multiethnic large cohort study including non-Hispanic White, African American, Japanese, Native Hawaiian, and Latino followed for a median of 10.7 years, the authors identified 13,437 cases with gallstone disease. Expected and significant risk factors across ethnic/racial populations were BMI over $25 \mathrm{~kg} / \mathrm{m}^{2}$, diabetes, past and current smoking, red meat consumption, saturated fat and cholesterol. Protective factors included vigorous physical activity and consumption of fruits, vegetables and foods rich in dietary fiber. Carbohydrates were inversely associated with gallbladder disease risk only among women and Latinos born in South America/Mexico, while parity was a significant risk factor among women. Postmenopausal hormones use increased the risk among nonHispanic White women [83].

In line with previous studies, sedentary physical activity has been directly related with hospital admission for gallbladder disease [84]. Using an internationally validated questionnaire, the European Prospective Investigation into Cancer (EPICNorfolk study) [85] investigated 25,639 volunteers (aged 40-74 years) for symptomatic gallstones. After 5 and 14 years, four groups of physical activity were examined. The risk of symptomatic gallstones was reduced by $70 \%$ in both sexes, with the highest association found in individuals exercising for 1 hour a day in a sedentary job, or 30 minutes a day in a standing job, or doing heavy manual job without any additional activity. The study suggests a causal protective effect of physical activity.

In a prospective study of 7,831 men with 471 incident cases of gallbladder disease (i.e. symptomatic gallstones), decreased physical activity, high BMI, cigarette smoking, and higher diastolic blood pressure increased the risk for clinical gallbladder disease [86]. Dyslipidemia is frequent in gallstone patients, who often have lower serum HDL and higher triglycerides levels, as compared to healthy control subjects [87]. A prior study involving inactive persons, marathoners and joggers found that physical activity levels were inversely associated with serum triglycerides [88]. Petitti et al. [29] reported that gallstone disease prevalence correlated positively to total, serum LDL/very low-density lipoprotein (VLDL) levels and triglycerides, and inversely to serum HDL levels. Thus, increasing physical activity can also be beneficial to cholelithiasis by lowering serum triglycerides [86], as well as other manifestations of dyslipidemia.

Hyperinsulinemia, a major component of the metabolic syndrome, promotes hepatic cholesterol uptake [89]. This condition, in turn, increases the secretion of biliary cholesterol [90], while reducing the secretion of bile acids (BA) [91]. These conditions predispose to the accumulation of cholesterol in 
bile, creating a supersaturated environment with excess of cholesterol [10, 92]. By contrast, regular exercise decreases insulin levels [93], as well as insulin resistance [94]. Physical activity also appears to stimulate hormonal mechanisms, such as the cholecystokinin-dependent gallbladder contraction [95], with a prokinetic effect on the intestine [96]. In this way, a regular program of physical activity would intercept and bring benefits on several pathogenic factors of (cholesterol) cholelithiasis.

In order to prevent gallstone disease and metabolic disorders $[6,13,97]$, keeping the ideal body weight is more important than losing excess of weight, as part of healthy lifestyles. Rapid weight loss, in fact, can lead to opposite effects. One third of these subjects have increased risk of gallstone formation due to rapid mobilization of body cholesterol and increased secretion in bile [33]. Therefore, the rapidity of weight loss, as well as the degree of obesity, are crucial in gallstones development [98]. In symptomatic gallstone patients, exercise may reduce pain perception, with mechanisms probably involving gallbladder motility and bile secretion [99].

Physical activity could also lead to a better health-related quality of life (HRQoL) in patients with gallstone disease $[100,101]$. Physical activity may imply less discomfort and reduced pain, as reported in several cohorts [102, 103]. Of note, patients with gallstone disease generally report decreased physical function and increased bodily pain [104, 105]. Several aspects in HRQoL, such as bodily pain or physical function, can improve postoperatively [106]. However, more studies are needed to better explore HRQoL outcomes in gallbladder patients [107]. Similar to the improvements observed in HRQoL after laparoscopic cholecystectomy [108], more clinical trials assessing the effect of physical activity in HRQoL should be considered in gallbladder disease.

The results of a systematic review and meta-analysis [109] based on eight selected studies $[60,74,80,85,86,110-112]$ confirm that high levels of physical activity reduce the risk of gallbladder disease. Further studies also support that vigorous physical activity is inversely associated with risk of gallbladder disease [83], and reduces the risk of cholecystectomy [113]. Higher levels of physical activity (above 16.6 METs/hour per week in males or 10.2 METs/hourper week in females) are able to reduce the occurrence of symptoms $[59,60]$. Vigorous physical activity protected against cholecystectomy in adult women [114]. Likewise, as reported in a five-year long study, higher levels of physical activity might be associated with a reduction of the risk for symptomatic gallstones by $70 \%$ [85]. Further research is necessary in this field, looking at the effects of dose-response relationship between physical activity and specific types of physical activity and pathophysiologic mechanisms leading to gallstones symptoms and complications in gallbladder disease, as well as in different populations. More objective measurements such as accelerometers might help in this respect [79].

Aerobic capacity plays a role with respect to gallstone disease. An increased aerobic capacity level is linked with a decreased prevalence of gallbladder disease [110, 115]. A protective role exists for both asymptomatic [114] or symptomatic (70\% risk reduction [85]) gallstone development, for gallbladder disease [109], and potentially for gallbladder cancer [116]. An increase in aerobic capacity of one MET reduces the odds of suffering from gallbladder disease by $8 \%$ in men and by $13 \%$ in women, respectively [115]. As mentioned earlier, vigorous aerobic physical activity is inversely associated with gallbladder risk, as measured by aerobic capacity [110]. Hospital admissions for gallbladder disease also appear to be inversely associated to physical activity [84, 117]. Remarkably, frequent aerobic exercise may favorably influence the progression of both gallbladder cancer and gallstones formation [116].

Physical activity is also able to modulate gastrointestinal motility $[118,119]$, by affecting the release of cholecystokinin (CCK), the pro-kinetic hormone $[99,120]$. The effects on CCK are also able to influence hunger (i.e. suppressing action), as shown in a study exploring acute aerobic physical activity (from 30 to $120 \mathrm{~min}$ ) [121]. One aspect to consider with respect to physical activity and gastrointestinal tract is the ongoing recirculation of BA within the enterohepatic circulation. Bile acids contribute to lipid components in bile, together with cholesterol and phospholipids. In the hepatocyte, primary BA are cholic acid and chenodeoxycholic acid, synthetized from cholesterol. Both BA are conjugated to taurine and glycine to increase their solubility in bile (Fig. 2A and 2B). Following secretion into the biliary tract, BA progressing to the terminal ileum and colon are bio-transformed into secondary BA (deoxycholic acid, litocholic acid) and tertiary BA (ursodeoxycholic acid) (Figure 2A) by the resident colonic microbiota. Approximately $95 \%$ of conjugated BA are reabsorbed (actively in the terminal ileum mainly, and about $15 \%$ passively in the colon) and return to the liver via the portal vein across the enterohepatic circulation [122]. Bile acids represent amphiphilic molecules which contribute to digestion and absorption of fat, cholesterol, and fat-soluble vitamins. Bile acids also act as signaling (hormonal) molecules and display antimicrobial and anti-inflammatory functions [122]. Thus, the study of the effects of physical activity on human body should also take into account the consequences in the enterohepatic circulation of BA. Prior animals studies show that moderate physical activity may increase BA excretion [123-125]. In turn, BA would activate the small intestinal farnesoid X receptor (FXR) with increased expression of the human enterokine fibroblast growth factor 19 (FGF19). This interaction results in activation of the FGF4 receptor/ $\beta$-clotho in the liver and small heterodimer-mediated inhibition of BA synthesis $[122,126]$, because of the reduced expression of hepatic cholesterol 7 $\alpha$-hydroxylase and BA synthesis [127]. In a mice study, however, BA secretion and fecal output increased after physical activity but the mechanism was increased with reverse cholesterol transport, independently from upregulation of genes involved in BA synthesis and FXR-FGF15 (FGF19 in humans) feedback [128]. In runners, both fecal and serum BA concentrations were decreased $[129,130]$, with decreased mutagenic secondary BA [130].

In the small intestine and in the liver, $\mathrm{BA}$ also activate another epithelial receptor, i.e., the $G$ protein bile acid receptor 1 (GPBAR-1) [131, 132]. This activation releases hormones such as peptide YY (PYY) with anorexigenic effect (i.e., appetite reduction) and glucagon-like peptides (GLP-1 and GLP-2) which produce effects in the glucose and insulin metabolism 

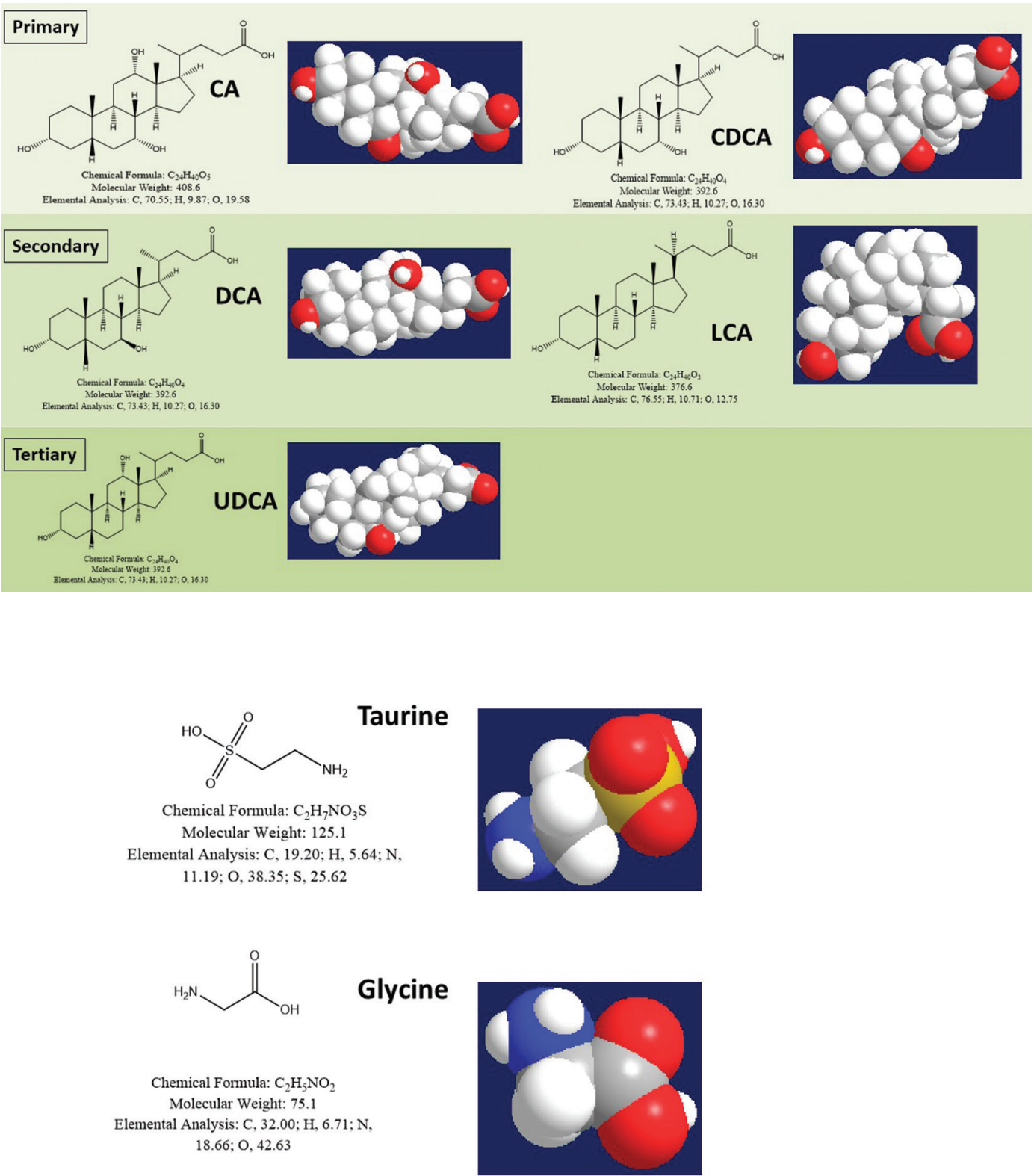

Fig. 2. A. Structure, chemical formula, molecular weight, elemental analysis and $3 \mathrm{D}$ formula of human bile acids. Primary bile acids are cholic acid (CA) and chenodeoxycholic acid (CDCA). Secondary bile acids are deoxycholic acid (DCA) and lithocholic acid (LCA). Tertiary bile acid is ursodeoxycholic acid (UDCA). B. Structure, chemical formula, molecular weight, elemental analysis and 3D formula of taurine and glycine which upon conjugation with bile acids increase their solubilization in bile.

[133]. GPBAR-1 localizes also in the gallbladder, brown adipose tissue, skeletal muscle, macrophages, and monocytes $[126,132]$, and in the enteroendocrine cells of the intestine $[122,134,135]$. In the skeletal muscle and brown adipose tissue, GPBAR-1 signaling leads to local activation of the type II iodothyronine deiodinase (DIO2), which transforms the inactive thyroxine (T4) to active thyroid hormone (T3, a key regulator of metabolism and energy homeostasis). In Kupffer cells and macrophages, GPBAR-1 activation inhibits Lipopolysaccharide (LPS)-induced cytokine production [136]. Such additional hormonal effects of BA are cAMP-mediated and might be particularly evident after bariatric surgery with important and beneficial metabolic effects, including increased energy expenditure, increased insulin secretion and/or sensitivity and decreased inflammatory status $[127,136,137]$.
Physical activity may also produce anti-inflammatory effects in the body. These anti-inflammatory effects could be promoted by GPBAR-1 activation, which is induced by circulating BA in the liver Kupffer cells [138]. Physical activity might partially mediate this effect $[139,140]$. Further, several anti-inflammatory changes are followed by BA-induced activation of GPBAR-1, which can be observed in other immune cells such as macrophages, monocytes, and dendritic cells [141]. These changes potentially induce further inhibition of NACHT, LRR and PYD domainscontaining protein 3 (NLRP3) inflammasome, which are protective against lipopolysaccharide-induced inflammation and atherosclerosis [142]. The additional anti-inflammatory effects might be induced by changes in gut microbiota induced by physical exercise [143]. In the enterohepatic circulation, 


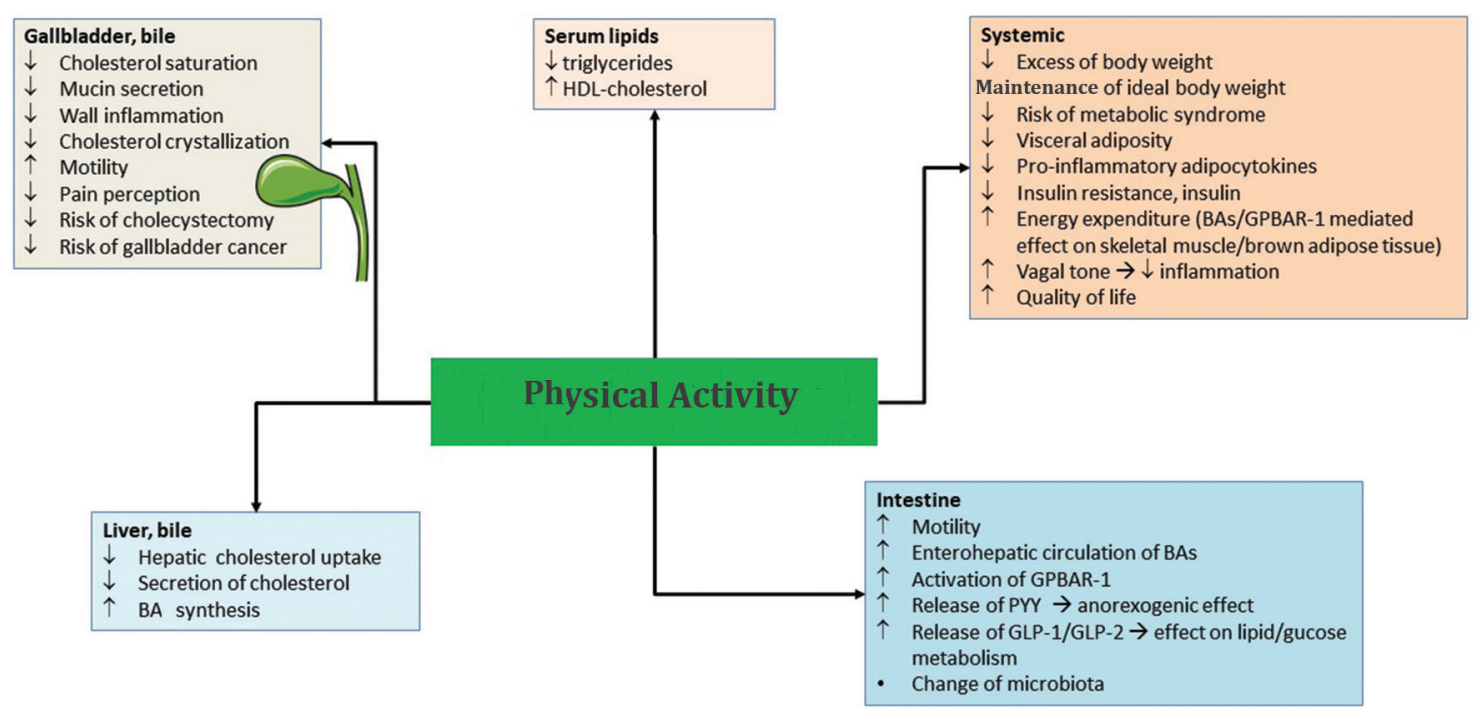

Fig. 3. Summary of the effects of physical activity on the gallbladder, and outside the gallbladder. With respect to cholelithiasis, beneficial effects can therefore activate either direct and/or indirect pathways.

Abbreviations: BA: bile acids; GLP-1/2: glucagon-like peptide 1/2; GPBAR-1: G protein bile acid receptor 1; PYY: peptide YY; $\uparrow:$ increased; $\downarrow$ : decreased. Image found on https://wallpapersafari.com/w/0O9mLa.

gut microbiota during physical exercise may also activate additional anti-inflammatory effects. The interaction of gut microbiota with $\mathrm{BA}$ in the enterohepatic circulation leads to the conversion of primary to secondary BA which, in turn, influence gut microbiota by exerting antimicrobial effects [144]. Ursodeoxycholic acid and lithocholic acid were recently shown to have anti-inflammatory properties by decreasing the release of pro-inflammatory cytokines while increasing the macrophage release of anti-inflammatory cytokines [144]

Furthermore, vagal tone is increased by regular physical activity $[145,146]$, which also decreases the expression of inflammatory markers [146]. However, studies have recently shown contradictory results, while others $[147,148]$ speculate a decrease in circulatory apoptosis to be correlated to increased aerobic capacity [149]. Also, gallbladder emptying, as mediated by vagal tone, could be a response of a neuro-hormonal product of physical exercise $[95,116]$.

\section{CONCLUSIONS}

Physical activity is an integral part of healthy lifestyles, contributing to the maintenance of ideal weight and, thus, counteracting the increasing burden of non-communicable diseases and metabolic abnormalities related to obesity and sedentary behaviors. The beneficial effects of regular physical activity on cardiovascular and metabolic disorders are well established. Aerobic physical activity also brings beneficial effects on the biliary tract, which include the prevention of gallstones, the decrease of gallstone-related symptoms and complications, as well as rate of hospitalization and a better quality of life. The beneficial effects of regular physical activity intercept several pathways, which go far beyond the direct effects on the gallbladder (i.e., improved kinetics and eased local inflammatory changes, decreased precipitation of crystallized cholesterol in the hypomotile viscus). More systemic anti-lithogenic effects of physical activity involve lipid metabolism, intestinal motility, insulin resistance, enterohepatic circulation of BA and their hormone-mediated energy expenditure, maintenance of body weight or decrease of excess body weight and, therefore, decreased impact of dysmetabolic pro-lithogenic factors (Fig. 3).

Thus, regular physical activity, as part of an overall healthy lifestyle plan, represents a plus for primary and secondary prevention of gallbladder disease, by the involvement of endorgan and systemic mechanisms.

Further studies should better explore distinctive outcomes of modality and intensity of physical activity, the harmful and beneficial effects of physical activity in populations of different ages and ethnicity, in different metabolic abnormalities, and in subjects exposed to different nutritional intake and environmental changes.

\section{Conflicts of interests: None to declare.}

Authors' contributions: H.S. and E.M.-M. wrote the article in equal contribution. D.M.D.P., M.F.F., A.D.C., L.B., D.Q.-H.W. and P.P.: article conception and reviewing.

Acknowledgments: The present chapter is written in the context of the projects FOIE GRAS (\#722619) and mtFOIE GRAS (\#734719), which have received funding from the European Union's Horizon 2020 Research and Innovation programme, under the Marie SkłodowskaCurie Grant Agreement.

\section{REFERENCES}

1. Portincasa P. Aging at the interface of biology and culture. In: Dumitrascu D, Krejs GJ, Sporea I. (eds.). Proceedings of the Central European Gastroenterology Meeting (GEURGEM), 13-15 February. 
Volume 1. Timisoara (Romania): Filodiritto Iternational Proceedings Editore 2019:108-116

2. Kodama S, Saito K, Tanaka S, et al. Cardiorespiratory fitness as a quantitative predictor of all-cause mortality and cardiovascular events in healthy men and women: a meta-analysis. JAMA 2009;301:2024-2035. doi:10.1001/jama.2009.681

3. Kim Y, Lee E. The association between elderly people's sedentary behaviors and their health-related quality of life: focusing on comparing the young-old and the old-old. Health Qual Life Outcomes 2019;17:131 doi:10.1186/s12955-019-1191-0

4. Ruiz JR, Labayen I, Ortega FB, et al. Physical activity, sedentary time, and liver enzymes in adolescents: the HELENA study. Pediatr Res 2014;75:798-802. doi:10.1038/pr.2014.26

5. Booth FW, Roberts CK, Laye MJ. Lack of exercise is a major cause of chronic diseases. Compr Physiol 2012;2:1143-1211. doi:10.1002/cphy. c110025

6. Faienza MF, Wang DQ, Frühbeck G, Garruti G, Portincasa P. The dangerous link between childhood and adulthood predictors of obesity and metabolic syndrome. Intern Emerg Med 2016;11:175-182. doi:10.1007/s11739-015-1382-6

7. Loria P, Lonardo A, Lombardini S, et al. Gallstone disease in nonalcoholic fatty liver: prevalence and associated factors. J Gastroenterol Hepatol 2005;20:1176-1184. doi:10.1111/j.1440-1746.2005.03924.x

8. Garruti G, Wang DQ, Di Ciaula A, Portincasa P. Cholecystectomy: a way forward and back to metabolic syndrome? Lab Invest 2018;98:4-6. doi:10.1038/labinvest.2017.129

9. Di Ciaula A, Garruti G, Wang DQ, Portincasa P. Cholecystectomy and risk of metabolic syndrome. Eur J Intern Med 2018;53:3-11. doi:10.1016/j.ejim.2018.04.019

10. Di Ciaula A, Wang DQ, Portincasa P. An update on the pathogenesis of cholesterol gallstone disease. Curr Opin Gastroenterol 2018;34:71-80. doi:10.1097/MOG.0000000000000423

11. American College of Sports Medicine. ACSM's Guidelines for Exercise Testing and Prescription. Ninth Edition. Lippincott Williams \& Wilkins; Baltimore, 2014.

12. NIH. Go4Life from the National Institute on Aging at the National Institute of Health (NIH). Accessed: April 2019. Available at:https:// go4life.nia.nih.gov/

13. Molina-Molina E, Lunardi Baccetto R, Wang DQ, de Bari O, Krawczyk M, Portincasa P. Exercising the hepatobiliary-gut axis. The impact of physical activity performance. Eur J Clin Invest 2018;48:e12958. doi:10.1111/eci.12958

14. Kenney WL, Wilmore JH, Costill DL. Physiology of sport and exercise. Human kinetics, Inc., Seventh edition. 2019.

15. US Department of Health and Human Services. 2008 Physical Activity Guidelines for Americans. 2008:1-76. Available at: https://health.gov/ paguidelines/2008/

16. Australian Government Department of Health. Australia's Physica Activity and Sedentary Behaviour Guidelines and the Australian 24Hour Movement Guidelines. Available at:http://www.health.gov.au/ internet/main/publishing.nsf/content/health-pubhlth-strateg-physact-guidelines, 2013.

17. Oja P, Bull FC, Fogelholm M, Martin BW. Physical activity recommendations for health: what should Europe do? BMC Public Health 2010;10:10. doi:10.1186/1471-2458-10-10

18. Warburton DE, Charlesworth S, Ivey A, Nettlefold L, Bredin SS. A systematic review of the evidence for Canada's Physical Activity Guidelines for Adults. Int J Behav Nutr Phys Act 2010;7:39. doi:10.1186/1479-5868-7-39
19. Tremblay MS, Warburton DE, Janssen I, et al. New Canadian physical activity guidelines. Appl Physiol Nutr Metab 2011;36:36-46. doi:10.1139/H11-009

20. Piercy KL, Troiano RP, Ballard RM, et al. The Physical Activity Guidelines for Americans. JAMA 2018;320:2020-2028. doi:10.1001/ jama.2018.14854

21. Hainer V, Toplak H, Stich V. Fat or fit: what is more important? Diabetes Care 2009;32 Suppl 2:S392-S397. doi:10.2337/dc09-S346

22. Tran ZV, Weltman A, Glass GV, Mood DP. The effects of exercise on blood lipids and lipoproteins: a meta-analysis of studies. Med Sci Sports Exerc 1983;15:393-402.

23. Leon AS, Sanchez OA. Response of blood lipids to exercise training alone or combined with dietary intervention. Med Sci Sports Exerc 2001;33(6 Suppl):S502-S515. doi:10.1097/00005768-200106001-00021

24. Baker TT, Allen D, Lei KY, Willcox KK. Alterations in lipid and protein profiles of plasma lipoproteins in middle-aged men consequent to an aerobic exercise program. Metabolism 1986;35:1037-1043. doi:10.1016/0026-0495(86)90040-5

25. Pedersen LR, Olsen RH, Anholm C, et al. Effects of 1 year of exercise training versus combined exercise training and weight loss on body composition, low-grade inflammation and lipids in overweight patients with coronary artery disease: a randomized trial. Cardiovasc Diabetol 2019;18:127. doi:10.1186/s12933-019-0934-х

26. Gupta AK, Ross EA, Myers JN, Kashyap ML. Increased reverse cholesterol transport in athletes. Metabolism 1993;42:684-690. doi:10.1016/0026-0495(93)90233-e

27. Wang DQH, Neuschwander-Tetri BA, Portincasa P. The Biliary System, Second Edition. San Rafael, CA (USA): Morgan \& Claypool Life Sciences, 2017.

28. Halloran LG, Schwartz CC, Vlahcevic ZR, Nisman RM, Swell L. Evidence for high-density lipoprotein-free cholesterol as the primary precursor for bile-acid synthesis in man. Surgery 1978;84:1-7.

29. Petitti DB, Friedman GD, Klatsky AL. Association of a history of gallbladder disease with a reduced concentration of high-densitylipoprotein cholesterol. N Engl J Med 1981;304:1396-1398. doi:10.1056/ NEJM198106043042305

30. Mingrone G, Greco AV, Arcieri Mastromattei E. Free fatty acids stimulate mucin hypersecretion by rabbit gall-bladder epithelium in vitro. Clin Sci (Lond) 1990;78:175-180. doi:10.1042/cs0780175

31. Mingrone G, Greco AV, Finotti E, Passi S. Free fatty acids: a stimulus for mucin hypersecretion in cholesterol gallstone biles. Biochim Biophys Acta 1988;958:52-59. doi:10.1016/0005-2760(88)90245-7

32. Portincasa P, Moschetta A, Palasciano G. Cholesterol gallstone disease Lancet 2006;368:230-239. doi:10.1016/S0140-6736(06)69044-2

33. Lammert F, Gurusamy K, Ko CW, et al. Gallstones. Nat Rev Dis Primers 2016;2:16024. doi:10.1038/nrdp.2016.24

34. Wang HH, Portincasa P, Wang DQ. Molecular pathophysiology and physical chemistry of cholesterol gallstones. Front Biosci 2008;13:401 423. doi: $10.2741 / 2688$

35. Baran J, Weres A, Czenczek-Lewandowska E, et al. Blood lipid profile and body composition in a pediatric population with different levels of physical activity. Lipids Health Dis 2018;17:171. doi:10.1186/s12944-018-0817-2

36. Craig SB, Bandini LG, Lichtenstein AH, Schaefer EJ, Dietz WH. The impact of physical activity on lipids, lipoproteins, and blood pressure in preadolescent girls. Pediatrics 1996;98:389-395.

37. Marrugat J, Elosua R, Covas MI, Molina L, Rubies-Prat J. Amount and intensity of physical activity, physical fitness, and serum lipids in men The MARATHOM Investigators. Am J Epidemiol 1996;143:562-569. doi:10.1093/oxfordjournals.aje.a008786 
38. Silva RC, Diniz Mde F, Alvim S, Vidigal PG, Fedeli LM, Barreto SM Physical Activity and Lipid Profile in the ELSA- Brasil Study. Arq Bras Cardiol 2016;107:10-19. doi:10.5935/abc.20160091

39. Shabanzadeh DM. Incidence of gallstone disease and complications. Curr Opin Gastroenterol 2018;34:81-89. doi:10.1097/ MOG.0000000000000418

40. Wang DQH, Portincasa P. (Eds). Gallstones. Recent advances in epidemiology, pathogenesis, diagnosis and management. New York: Nova Science Publisher Inc., 2017.

41. Attili AF, Carulli N, Roda E, et al. Epidemiology of gallstone disease in Italy: prevalence data of the Multicenter Italian Study on Cholelithiasis (M.I.COL.). Am J Epidemiol 1995;141:158-165. doi:10.1093/ oxfordjournals.aje.a117403

42. Portincasa P, Wang DQH. Gallstones. In: Podolsky KD, Camilleri M, Fitz JG, Kalloo AN, Shanahan F, Wang TC. (eds.). Yamada's Textbook of Gastroenterology. 6th ed. Hoboken, New Jersey (USA): WileyBlackwell, 2015:1808-1834.

43. Portincasa P, Wang DQH. Gallstones. In: Podolsky KD, Camilleri M, Fitz JG, Kalloo AN, Shanahan F, Wang TC. (eds.). Yamada's Atlas of Gastroenterology. 5th ed. Hoboken, New Jersey (USA): WileyBlackwell, 2016:335-353.

44. Portincasa P, Molina-Molina E, Garruti G, Wang DQ. Critical Care Aspects of Gallstone Disease. J Crit Care Med (Targu Mures) 2019;5:618. doi:10.2478/jccm-2019-0003

45. Farthing M, Roberts SE, Samuel DG, et al. Survey of digestive health across Europe: Final report. Part 1: The burden of gastrointestinal diseases and the organisation and delivery of gastroenterology services across Europe. United European Gastroenterol J 2014;2:539-543. doi:10.1177/2050640614554154

46. Attili AF, Capocaccia R, Carulli N, et al. Factors associated with gallstone disease in the MICOL experience. Multicenter Italian Study on Epidemiology of Cholelithiasis. Hepatology 1997;26:809-818. doi:10.1002/hep.510260401

47. Diehl AK. Epidemiology and natural history of gallstone disease. Gastroenterol Clin North Am 1991;20:1-19.

48. Grundy SM. Cholesterol gallstones: a fellow traveler with metabolic syndrome? Am J Clin Nutr 2004;80:1-2. doi:10.1093/ajcn/80.1.1

49. Sherlock S, Dooley J. Diseases of the liver and biliary system. Oxford: Blackwell Science, 2002

50. Trotman BW, Ostrow JD, Soloway RD. Pigment vs cholesterol cholelithiasis: comparison of stone and bile composition. Am J Dig Dis 1974;19:585-590. doi:10.1007/bf01073011

51. European Association for the Study of the Liver. EASL Clinical Practice Guidelines on the prevention, diagnosis and treatment of gallstones. J Hepatol 2016;65:146-181. doi:10.1016/j.jhep.2016.03.005

52. Friedman GD, Kannel WB, Dawber TR. The epidemiology of gallbladder disease: observations in the Framingham Study. J Chronic Dis 1966;19:273-292. doi:10.1016/0021-9681(66)90132-9

53. Ruhl CE, Everhart JE. Association of diabetes, serum insulin, and C-peptide with gallbladder disease. Hepatology 2000;31:299-303. doi:10.1002/hep.510310206

54. Haffner SM, Diehl AK, Mitchell BD, Stern MP, Hazuda HP. Increased prevalence of clinical gallbladder disease in subjects with non-insulindependent diabetes mellitus. Am J Epidemiol 1990;132:327-335 doi:10.1093/oxfordjournals.aje.a115662

55. Misciagna G, Guerra V, Di Leo A, Correale M, Trevisan M. Insulin and gall stones: a population case control study in southern Italy. Gut 2000;47:144-147. doi:10.1136/gut.47.1.144
56. Weikert C, Weikert S, Schulze MB, et al. Presence of gallstones or kidney stones and risk of type 2 diabetes. Am J Epidemiol 2010;171:447-454 doi:10.1093/aje/kwp411

57. Biddinger SB, Haas JT, Yu BB, et al. Hepatic insulin resistance directly promotes formation of cholesterol gallstones. Nat Med 2008;14:778-782. doi:10.1038/nm1785

58. Banim PJ, Luben RN, Bulluck H, et al. The aetiology of symptomatic gallstones quantification of the effects of obesity, alcohol and serum lipids on risk. Epidemiological and biomarker data from a UK prospective cohort study (EPIC-Norfolk). Eur J Gastroenterol Hepatol 2011;23:733-740. doi:10.1097/MEG.0b013e3283477cc9

59. Stender S, Nordestgaard BG, Tybjaerg-Hansen A. Elevated body mass index as a causal risk factor for symptomatic gallstone disease: a Mendelian randomization study. Hepatology 2013;58:2133-2141. doi:10.1002/hep.26563

60. Leitzmann MF, Rimm EB, Willett WC, et al. Recreational physical activity and the risk of cholecystectomy in women. N Engl J Med 1999;341:777-784. doi:10.1056/NEJM199909093411101

61. The epidemiology of gallstone disease in Rome, Italy. Part I. Prevalence data in men. The Rome Group for Epidemiology and Prevention of Cholelithiasis (GREPCO). Hepatology 1988;8:904-906. doi:10.1002/ hep. 1840080433

62. Volzke H, Baumeister SE, Alte D, et al. Independent risk factors for gallstone formation in a region with high cholelithiasis prevalence. Digestion 2005;71:97-105. doi:10.1159/000084525

63. Maclure KM, Hayes KC, Colditz GA, Stampfer MJ, Speizer FE, Willett WC. Weight, diet, and the risk of symptomatic gallstones in middle-aged women. N Engl J Med 1989;321:563-569. doi:10.1056/ NEJM198908313210902

64. Tsai CJ, Leitzmann MF, Willett WC, Giovannucci EL. Central adiposity, regional fat distribution, and the risk of cholecystectomy in women. Gut 2006;55:708-714. doi:10.1136/gut.2005.076133

65. Klein S, Wadden T, Sugerman HJ. AGA technical review on obesity. Gastroenterology 2002;123:882-932. doi:10.1053/gast.2002.35514

66. Scragg RK, McMichael AJ, Baghurst PA. Diet, alcohol, and relative weight in gall stone disease: a case-control study. Br Med J (Clin Res Ed) 1984;288:1113-1119. doi:10.1136/bmj.288.6424.1113

67. Stampfer MJ, Maclure KM, Colditz GA, Manson JE, Willett WC. Risk of symptomatic gallstones in women with severe obesity. Am J Clin Nutr 1992;55:652-658. doi:10.1093/ajcn/55.3.652

68. Lammert F, Wang DQ, Wittenburg $\mathrm{H}$, et al. Lith genes control mucin accumulation, cholesterol crystallization, and gallstone formation in $\mathrm{A} / \mathrm{J}$ and AKR/J inbred mice. Hepatology 2002;36:1145-1154. doi:10.1053/ jhep.2002.36821

69. Wang DQ, Afdhal NH. Genetic analysis of cholesterol gallstone formation: searching for Lith (gallstone) genes. Curr Gastroenterol Rep 2004;6:140-150. doi:10.1007/s11894-004-0042-1

70. Wang TY, Portincasa P, Liu M, Tso P, Wang DQ. Mouse models of gallstone disease. Curr Opin Gastroenterol 2018;34:59-70. doi:10.1097/ MOG.0000000000000417

71. Sedaghat A, Grundy SM. Cholesterol crystals and the formation of cholesterol stones. N Engl J Med 1980;302:1274-1277. doi:10.1056/ NEJM198006053022302

72. Wang DQ, Carey MC. Complete mapping of crystallization pathways during cholesterol precipitation from model bile: influence of physicalchemical variables of pathophysiologic relevance and identification of a stable liquid crystalline state in cold, dilute and hydrophilic bile salt-containing systems. J Lipid Res 1996;37:606-630. 
73. Grattagliano I, Wang DQ, Di Ciaula A, Diogo CV, Palasciano G, Portincasa P. Biliary proteins and their redox status changes in gallstone patients. Eur J Clin Invest 2009;39:986-992. doi:10.1111/j.13652362.2009.02187.x

74. Leitzmann MF, Giovannucci EL, Rimm EB, et al. The relation of physical activity to risk for symptomatic gallstone disease in men. Ann Intern Med 1998;128:417-425. doi:10.7326/0003-4819-128-6-199803150-00001

75. Misciagna G, Centonze S, Leoci C, et al. Diet, physical activity, and gallstones--a population-based, case- control study in southern Italy. Am J Clin Nutr 1999;69:120-126. doi:10.1093/ajcn/69.1.120

76. Walcher T, Haenle MM, Mason RA, et al. The effect of alcohol, tobacco and caffeine consumption and vegetarian diet on gallstone prevalence. Eur J Gastroenterol Hepatol 2010;22:1345-1351. doi:10.1097/ MEG.0b013e32833efdb2

77. Ortega RM, Fernandez-Azuela M, Encinas-Sotillos A, Andres P, LopezSobaler AM. Differences in diet and food habits between patients with gallstones and controls. J Am Coll Nutr 1997;16:88-95. doi:10.1080/0 7315724.1997.10718655

78. Utter AC, Whitcomb DC, Nieman DC, Butterworth DE, Vermillion SS. Effects of exercise training on gallbladder function in an obese female population. Med Sci Sports Exerc 2000;32:41-45. doi:10.1097/00005768200001000-00007

79. Kriska AM, Brach JS, Jarvis BJ, et al. Physical activity and gallbladder disease determined by ultrasonography. Med Sci Sports Exerc 2007;39:1927-1932. doi:10.1249/mss.0b013e3181484d0e

80. Storti KL, Brach JS, FitzGerald SJ, Zmuda JM, Cauley JA, Kriska AM. Physical activity and decreased risk of clinical gallstone disease among post-menopausal women. Prev Med 2005;41:772-777. doi:10.1016/j. ypmed.2005.04.002

81. Kato I, Tominaga S. Factors associated with levels of physical activity at work and during leisure time. Nihon Koshu Eisei Zasshi 1992;39:822829.

82. Farrell GC. The liver and the waistline: Fifty years of growth. J Gastroenterol Hepatol 2009;24 Suppl 3:S105-S118. doi:10.1111/j.14401746.2009.06080.x

83. Figueiredo JC, Haiman C, Porcel J, et al. Sex and ethnic/racial-specific risk factors for gallbladder disease. BMC Gastroenterol 2017;17:153. doi:10.1186/s12876-017-0678-6

84. Shabanzadeh DM. New determinants for gallstone disease? Dan Med J 2018;65:B5436.

85. Banim PJ, Luben RN, Wareham NJ, Sharp SJ, Khaw KT, Hart AR Physical activity reduces the risk of symptomatic gallstones: a prospective cohort study. Eur J Gastroenterol Hepatol 2010;22:983-988. doi:10.1097/MEG.0b013e32833732c3

86. Kato I, Nomura A, Stemmermann GN, Chyou PH. Prospective study of clinical gallbladder disease and its association with obesity, physical activity, and other factors. Dig Dis Sci 1992;37:784-790. doi:10.1007/ bf01296440

87. Hayat S, Hassan Z, Changazi SH, et al. Comparative analysis of serum lipid profiles in patients with and without gallstones: A prospective cross-sectional study. Ann Med Surg (Lond) 2019;42:11-13. doi:10.1016/j.amsu.2019.04.003

88. Diehl AK, Haffner SM, Hazuda HP, Stern MP. Coronary risk factors and clinical gallbladder disease: an approach to the prevention of gallstones? Am J Public Health 1987;77:841-845. doi:10.2105/ajph.77.7.841

89. Chait A, Bierman EL, Albers JJ. Low-density lipoprotein receptor activity in cultured human skin fibroblasts. Mechanism of insulin-induced stimulation. J Clin Invest 1979;64:1309-1319. doi:10.1172/JCI109587
90. Nepokroeff CM, Lakshmanan MR, Ness GC, Dugan RE, Porter JW. Regulation of the diurnal rhythm of rat liver beta-hydroxy-betamethylglutaryl coenzmye A reductase activity by insulin, glucagon, cyclic AMP and hydrocortisone. Arch Biochem Biophys 1974;160:387396. doi:10.1016/0003-9861(74)90412-3

91. Subbiah MT, Yunker RL. Cholesterol 7 alpha-hydroxylase of rat liver: an insulin sensitive enzyme. Biochem Biophys Res Commun 1984;124:896902. doi:10.1016/0006-291x(84)91042-8

92. Di Ciaula A, Portincasa P. Recent advances in understanding and managing cholesterol gallstones. F1000Res 2018;7:F1000 Faculty Rev1529. doi:10.12688/f1000research.15505.1

93. Kirwan JP, Kohrt WM, Wojta DM, Bourey RE, Holloszy JO. Endurance exercise training reduces glucose-stimulated insulin levels in 60to 70-year-old men and women. J Gerontol 1993;48:M84-M90. doi:10.1093/geronj/48.3.m84

94. Seals DR, Hagberg JM, Hurley BF, Ehsani AA, Holloszy JO. Effects of endurance training on glucose tolerance and plasma lipid levels in older men and women. JAMA 1984;252:645-649. doi:10.1001/ jama.1984.03350050033022

95. Philipp E, Wilckens T, Friess E, Platte P, Pirke KM. Cholecystokinin, gastrin and stress hormone responses in marathon runners. Peptides 1992;13:125-128. doi:10.1016/0196-9781(92)90150-2

96. Koffler KH, Menkes A, Redmond RA, Whitehead WE, Pratley RE, Hurley BF. Strength training accelerates gastrointestinal transit in middle-aged and older men. Med Sci Sports Exerc 1992;24:415-419.

97. Bonfrate L, Wang DQ, Garruti G, Portincasa P. Obesity and the risk and prognosis of gallstone disease and pancreatitis. Best Pract Res Clin Gastroenterol 2014;28:623-635. doi:10.1016/j.bpg.2014.07.013

98. Heida A, Koot BG, vd Baan-Slootweg OH, et al. Gallstone disease in severely obese children participating in a lifestyle intervention program: incidence and risk factors. Int J Obes (Lond) 2014;38:950-953. doi:10.1038/ijo.2014.12

99. Utter A, Goss F. Exercise and gall bladder function. Sports Med 1997;23:218-227. doi:10.2165/00007256-199723040-00002

100. Carrilho-Ribeiro L, Serra D, Pinto-Correia A, Velosa J, De Moura MC. Quality of life after cholecystectomy and after successful lithotripsy for gallbladder stones: a matched-pairs comparison. Eur J Gastroenterol Hepatol 2002;14:741-744. doi:10.1097/00042737-200207000-00005

101. Vetrhus M, Soreide O, Eide GE, Solhaug JH, Nesvik I, Sondenaa K. Pain and quality of life in patients with symptomatic, non-complicated gallbladder stones: results of a randomized controlled trial. Scand J Gastroenterol 2004;39:270-276. doi:10.1080/00365520310008502

102. Chou CH, Hwang CL, Wu YT. Effect of exercise on physical function, daily living activities, and quality of life in the frail older adults: a meta-analysis. Arch Phys Med Rehabil 2012;93:237-244. doi:10.1016/j. apmr.2011.08.042

103. Dugan SA, Everson-Rose SA, Karavolos K, Sternfeld B, Wesley D, Powell LH. The impact of physical activity level on SF-36 role-physical and bodily pain indices in midlife women. J Phys Act Health 2009;6:33-42. doi:10.1123/jpah.6.1.33

104. Cobden I, Lendrum R, Venables CW, James OF. Gallstones presenting as mental and physical debility in the elderly. Lancet 1984;1:1062-1064. doi:10.1016/s0140-6736(84)91462-4

105. Njeze GE. Gallstones. Niger J Surg 2013;19:49-55.

106. Palsson SH, Rasmussen I, Lundstrom P, Osterberg J, Sandblom G. Registration of health-related quality of life in a cohort of patients undergoing cholecystectomy. ISRN Gastroenterol 2011;2011:507389. doi:10.5402/2011/507389 
107. Cinar H, Topgul K, Malazgirt Z, et al. Early results of single-incision laparoscopic cholecystectomy in comparison with the conventional: Does it have any impact on quality of life? Ann Med Surg (Lond) 2018;32:1-5. doi:10.1016/j.amsu.2018.06.002

108. Lien HH, Huang CC, Wang PC, et al. Changes in quality-of-life following laparoscopic cholecystectomy in adult patients with cholelithiasis. J Gastrointest Surg 2010;14:126-130. doi:10.1007/s11605009-1062-9

109. Aune D, Leitzmann M, Vatten LJ. Physical Activity and the Risk of Gallbladder Disease: A Systematic Review and Meta-Analysis of Cohort Studies. J Phys Act Health 2016;13:788-795. doi:10.1123/jpah.20150456

110. Williams PT. Independent effects of cardiorespiratory fitness, vigorous physical activity, and body mass index on clinical gallbladder disease risk. Am J Gastroenterol 2008;103:2239-2247.

111. Boland LL, Folsom AR, Rosamond WD, Atherosclerosis Risk in Communities Study Investigators. Hyperinsulinemia, dyslipidemia, and obesity as risk factors for hospitalized gallbladder disease. A prospective study. Ann Epidemiol 2002;12:131-140. doi:10.1016/s10472797(01)00260-5

112. Sahi T, Paffenbarger RS Jr, Hsieh CC, Lee IM. Body mass index, cigarette smoking, and other characteristics as predictors of self-reported, physician-diagnosed gallbladder disease in male college alumni. Am J Epidemiol 1998;147:644-651. doi:10.1093/oxfordjournals.aje.a009505

113. Talseth A, Ness-Jensen E, Edna TH, Hveem K. Risk factors for requiring cholecystectomy for gallstone disease in a prospective population-based cohort study. Br J Surg 2016;103:1350-1357. doi:10.1002/bjs.10205

114. Henao-Moran S, Denova-Gutierrez E, Moran S, et al. Recreational physical activity is inversely associated with asymptomatic gallstones in adult Mexican women. Ann Hepatol 2014;13:810-818. doi:10.1016/ S1665-2681(19)30984-6

115. Li C, Mikus C, Ahmed A, et al. A cross-sectional study of cardiorespiratory fitness and gallbladder disease. Ann Epidemiol 2017;27:269-273.e3. doi:10.1016/j.annepidem.2016.11.001

116. Shephard RJ. Physical Activity and the Biliary Tract in Health and Disease. Sports Med 2015;45:1295-1309. doi:10.1007/s40279-015-0346-3

117. Shabanzadeh DM, Sorensen LT, Jorgensen T. Determinants for clinical events in gallstone carriers unaware of their gallstones. J Gastroenterol Hepatol 2017;32:721-726. doi:10.1111/jgh.13531

118. Portincasa P, Di Ciaula A, vanBerge-Henegouwen GP. Smooth muscle function and dysfunction in gallbladder disease. Curr Gastroenterol Rep 2004;6:151-162. doi:10.1007/s11894-004-0043-0

119. Portincasa P, Di Ciaula A, Baldassarre G, et al. Gallbladder motor function in gallstone patients: sonographic and in vitro studies on the role of gallstones, smooth muscle function and gallbladder wall inflammation. J Hepatol 1994;21:430-440. doi:10.1016/s01688278(05)80324-1

120. Krishnamurthy S, Krishnamurthy GT. Biliary dyskinesia: role of the sphincter of Oddi, gallbladder and cholecystokinin. J Nucl Med 1997;38:1824-1830.

121. Schubert MM, Desbrow B, Sabapathy S, Leveritt M. Acute exercise and subsequent energy intake. A meta-analysis. Appetite 2013;63:92-104 doi:10.1016/j.appet.2012.12.010

122. Di Ciaula A, Garruti G, Lunardi Baccetto R, et al. Bile Acid Physiology. Ann Hepatol 2017;16 Suppl 1:s4-s14. doi:10.5604/01.3001.0010.5493

123. Yiamouyiannis CA, Martin BJ, Watkins JB 3rd. Chronic physical activity alters hepatobiliary excretory function in rats. J Pharmacol Exp Ther 1993;265:321-327.
124. Watkins JB 3rd, Crawford ST, Sanders RA. Chronic voluntary exercise may alter hepatobiliary clearance of endogenous and exogenous chemicals in rats. Drug Metab Dispos 1994;22:537-543.

125. Bouchard G, Carrillo MC, Tuchweber B, et al. Moderate long-term physical activity improves the age-related decline in bile formation and bile salt secretion in rats. Proc Soc Exp Biol Med 1994;206:409-415. doi:10.3181/00379727-206-43779

126. Li T, Chiang JY. Bile acid signaling in metabolic disease and drug therapy. Pharmacol Rev 2014;66:948-983. doi:10.1124/ pr.113.008201

127. Mazidi M, de Caravatto PP, Speakman JR, Cohen RV. Mechanisms of Action of Surgical Interventions on Weight-Related Diseases: the Potential Role of Bile Acids. Obes Surg 2017;27:826-836. doi:10.1007/ s11695-017-2549-1

128. Meissner M, Lombardo E, Havinga R, Tietge UJ, Kuipers F, Groen AK. Voluntary wheel running increases bile acid as well as cholesterol excretion and decreases atherosclerosis in hypercholesterolemic mice. Atherosclerosis 2011;218:323-329. doi:10.1016/j.atherosclerosis.2011.06.040

129. Sutherland WH, Nye ER, Macfarlane DJ, Robertson MC, Williamson SA. Fecal bile acid concentration in distance runners. Int J Sports Med 1991;12:533-536. doi:10.1055/s-2007-1024729

130. Danese E, Salvagno GL, Tarperi C, et al. Middle-distance running acutely influences the concentration and composition of serum bile acids: Potential implications for cancer risk? Oncotarget 2017;8:5277552782. doi:10.18632/oncotarget.17188

131. Festa C, De Marino S, Carino A, et al. Targeting Bile Acid Receptors: Discovery of a Potent and Selective Farnesoid X Receptor Agonist as a New Lead in the Pharmacological Approach to Liver Diseases. Front Pharmacol 2017;8:162. doi:10.3389/fphar.2017.00162

132. de Aguiar Vallim TQ, Tarling EJ, Edwards PA. Pleiotropic roles of bile acids in metabolism. Cell Metab 2013;17:657-669. doi:10.1016/j. cmet.2013.03.013

133. Liu N, Zhao J, Wang J, Teng H, Fu Y, Yuan H. Farnesoid X receptor ligand CDCA suppresses human prostate cancer cells growth by inhibiting lipid metabolism via targeting sterol response element binding protein 1. Am J Transl Res 2016;8:5118-5124.

134. Barrasa JI, Olmo N, Lizarbe MA, Turnay J. Bile acids in the colon, from healthy to cytotoxic molecules. Toxicol In Vitro 2013;27:964-977. doi:10.1016/j.tiv.2012.12.020

135. Brighton CA, Rievaj J, Kuhre RE, et al. Bile Acids Trigger GLP-1 Release Predominantly by Accessing Basolaterally Located G Protein-Coupled Bile Acid Receptors. Endocrinology 2015;156:3961-3970. doi:10.1210/ en.2015-1321

136. Schaap FG, Trauner M, Jansen PL. Bile acid receptors as targets for drug development. Nat Rev Gastroenterol Hepatol 2014;11:55-67. doi:10.1038/nrgastro.2013.151

137. Wahlström A, Sayin SI, Marschall HU, Bäckhed F. Intestinal crosstalk between bile acids and microbiota and its impact on host metabolism Cell Metab 2016;24:41-50. doi:10.1016/j.cmet.2016.05.005

138. Dixon LJ, Barnes M, Tang H, Pritchard MT, Nagy LE. Kupffer cells in the liver. Compr Physiol 2013;3:785-797. doi:10.1002/cphy.c120026

139. Oh S, So R, Shida T, et al. High-Intensity Aerobic Exercise Improves Both Hepatic Fat Content and Stiffness in Sedentary Obese Men with Nonalcoholic Fatty Liver Disease. Sci Rep 2017;7:43029. doi:10.1038/ srep43029

140. Komine S, Akiyama K, Warabi E, et al. Exercise training enhances in vivo clearance of endotoxin and attenuates inflammatory responses 
by potentiating Kupffer cell phagocytosis. Sci Rep 2017;7:11977. doi:10.1038/s41598-017-12358-8

141. Lewis ND, Patnaude LA, Pelletier J, et al. A GPBAR1 (TGR5) small molecule agonist shows specific inhibitory effects on myeloid cell activation in vitro and reduces experimental autoimmune encephalitis (EAE) in vivo. PLoS One 2014;9:e100883. doi:10.1371/journal.pone.0100883

142. Chavez-Talavera O, Tailleux A, Lefebvre P, Staels B. Bile Acid Control of Metabolism and Inflammation in Obesity, Type 2 Diabetes, Dyslipidemia, and Nonalcoholic Fatty Liver Disease. Gastroenterology 2017;152:1679-1694.e3. doi:10.1053/j.gastro.2017.01.055

143. Allen JM, Mailing LJ, Niemiro GM, et al. Exercise Alters Gut Microbiota Composition and Function in Lean and Obese Humans. Med Sci Sports Exerc 2018;50:747-757. doi:10.1249/MSS.0000000000001495

144. Ward JBJ, Lajczak NK, Kelly OB, et al. Ursodeoxycholic acid and lithocholic acid exert anti-inflammatory actions in the colon. Am J Physiol Gastrointest Liver Physiol 2017;312:G550-G558. doi:10.1152/ ajpgi.00256.2016

145. Kai S, Nagino K, Ito T, et al. Effectiveness of Moderate Intensity Interval Training as an Index of Autonomic Nervous Activity. Rehabil Res Pract 2016;2016:6209671. doi:10.1155/2016/6209671

146. Sloan RP, McCreath H, Tracey KJ, Sidney S, Liu K, Seeman T. RR interval variability is inversely related to inflammatory markers: the CARDIA study. Mol Med 2007;13:178-184. doi:10.2119/2006-00112.Sloan

147. Houghton D, Thoma C, Hallsworth K, et al. Exercise Reduces Liver Lipids and Visceral Adiposity in Patients With Nonalcoholic Steatohepatitis in a Randomized Controlled Trial. Clin Gastroenterol Hepatol 2017;15:96-102.e3. doi:10.1016/j.cgh.2016.07.031

148. Fealy CE, Haus JM, Solomon TP, et al. Short-term exercise reduces markers of hepatocyte apoptosis in nonalcoholic fatty liver disease. J Appl Physiol (1985) 2012;113:1-6. doi:10.1152/ japplphysiol.00127.2012
149. Bonaz B, Sinniger V, Pellissier S. The Vagus Nerve in the Neuro-Immune Axis: Implications in the Pathology of the Gastrointestinal Tract. Front Immunol 2017;8:1452. doi:10.3389/fimmu.2017.01452

150. Portincasa P, van Erpecum KJ, Di Ciaula A, Wang DQ. The physical presence of gallstone modulates ex vivo cholesterol crystallization pathways of human bile. Gastroenterol Rep (Oxf) 2019;7:32-41. doi:10.1093/gastro/goy044

151. Di Ciaula A, Wang DQ, Portincasa P. Cholesterol cholelithiasis: part of a systemic metabolic disease, prone to primary prevention. Expert Rev Gastroenterol Hepatol 2019;13:157-171. doi:10.1080/17474124.2019.1 549988

152. Wang HH, Li T, Portincasa P, et al. New insights into the role of Lith genes in the formation of cholesterol-supersaturated bile. Liver Research 2017;1:42-53. doi:10.1016/j.livres.2017.05.005

153. Wang DQ, Portincasa P, Tso P. Transintestinal cholesterol excretion: A secondary, nonbiliary pathway contributing to reverse cholesterol transport. Hepatology 2017;66:1337-1340. doi:10.1002/hep.29341

154. Portincasa P, Wang DQ. Effect of Inhibition of Intestinal Cholesterol Absorption on the Prevention of Cholesterol Gallstone Formation. Med Chem 2017;13:421-429. doi:10.2174/1573406413666170209122 851

155. Portincasa P, Bonfrate L, Di Ciaula A, et al. Diet and Gallstones. In: Wang $\mathrm{DQH}$, Portincasa P. (eds.). Gallstones. Recent advances in epidemiology, pathogenesis, diagnosis and management. New York: Nova Science Publisher Inc., 2017:297-322.

156. Di Ciaula A, Garruti G, Fruhbeck G, et al. The role of diet in the pathogenesis of cholesterol gallstones. Curr Med Chem 2019;26:36203638. doi:10.2174/0929867324666170530080636

157. Wang HH, Portincasa P, Wang DQ. The cholecystokinin-1 receptor antagonist devazepide increases cholesterol cholelithogenesis in mice. Eur J Clin Invest 2016;46:158-169. doi:10.1111/eci.12580 